\title{
Climate Change and Rural Development in the Middle Atlas Mountains and Fringe Areas (Morocco)
}

Moulay-Driss El Jihad

\section{(2) OpenEdition \\ 1 Journals}

Electronic version

URL: https://journals.openedition.org/rga/3465

DOI: $10.4000 /$ rga.3465

ISSN: $1760-7426$

This article is a translation of:

Changement climatique et développement rural dans les montagnes du Moyen-Atlas et leurs

bordures (Maroc) - URL : https://journals.openedition.org/rga/3373 [fr]

Publisher.

Association pour la diffusion de la recherche alpine, UGA Éditions/Université Grenoble Alpes

Electronic reference

Moulay-Driss El Jihad, "Climate Change and Rural Development in the Middle Atlas Mountains and Fringe Areas (Morocco)", Journal of Alpine Research / Revue de géographie alpine [Online], 104-4 | 2016, Online since 05 October 2016, connection on 08 December 2022. URL: http://journals.openedition.org/ rga/3465; DOI: https://doi.org/10.4000/rga.3465

This text was automatically generated on 8 December 2022

\section{(c) (†) $\ominus$}

Creative Commons - Attribution-NonCommercial-NoDerivatives 4.0 International - CC BY-NC-ND 4.0 https://creativecommons.org/licenses/by-nc-nd/4.0/ 


\title{
Climate Change and Rural Development in the Middle Atlas Mountains and Fringe Areas (Morocco)
}

\author{
Moulay-Driss El Jihad
}

\section{Introduction}

1 Mountains are a key feature of Morocco's geography. The Atlas area, which is separated from the Rif by the Fez-Taza corridor, runs diagonally down the backbone of the country from the Northeast to the Southwest, separating the plains and plateaus of central Atlantic Morocco from the vast pre-Saharan and Saharan areas. For nearly a century, the pastoral ecosystems of the Moroccan mountains have been under considerable pressure (demographic surge, livestock increase, state appropriation of forests, extension of crops at the expense of rangelands). Since the 1970s, the Middle Atlas pastoral society, once dominated by transhumance, has evolved into one that remains tied to grazing areas, and mobility tends to be increasingly restricted.

Human and animal pressure is all the more detrimental to the conservation of soils and forests since ongoing climate change is having a negative impact on the regenerative capacity of these resources. Until the 1990s, all rural development projects (RDPs) focused on mountain areas had been strictly confined to a strategy that prioritised the fight against soil erosion, which threatens to silt up dams. The RDPs undertaken since the early 2000s have been geared towards a participatory and integrated approach to rural development issues.

3 In this study, we intend to analyse the links between rural development policies and climate change in the Middle Atlas since the 1960s. What we propose is a geopolitical and critical approach to these policies and their effects on ecosystems and populations. Geopolitics is taken here in the sense of Rosière (2007), i.e. a discipline that considers 
space as an issue and involves "special attention to be paid to actors, their mutual relations and their relations to territories". On the basis of this definition, this study will firstly address the evolution of the controversies regarding and the differences between development models launched by the Moroccan administration and foreign donors as they relate to measures in favour of soil and forest conservation. It will also assess to what extent development policies respond to the territorial issues raised by climate change in terms of population resilience and the sustainability of natural resources in a mountain environment that is undergoing strong anthropic pressure.

\section{The Middle Atlas and climate change: the current situation and future prospects}

In the heart of northern Morocco, between the Rif and the High Atlas, the Middle Atlas is a major component of the Moroccan terrain (fig. 1). It runs about $450 \mathrm{~km}$ from the Southwest to the Northeast and covers a total area of $27,550 \mathrm{~km}^{2}$, which is $15 \%$ of the country's total mountain area. The Middle Atlas is $100 \mathrm{~km}$ wide in the North and only $30 \mathrm{~km}$ wide in the South. In addition to its topographic boundaries (around 1,000 metres), the Middle Atlas is characterised by the ubiquitous Jurassic, mostly limestone, outcrops that make this mountain the main water reservoir of Morocco, whose inputs are affected by ongoing climate change.

Figure 1: The Middle Atlas in its geographical context

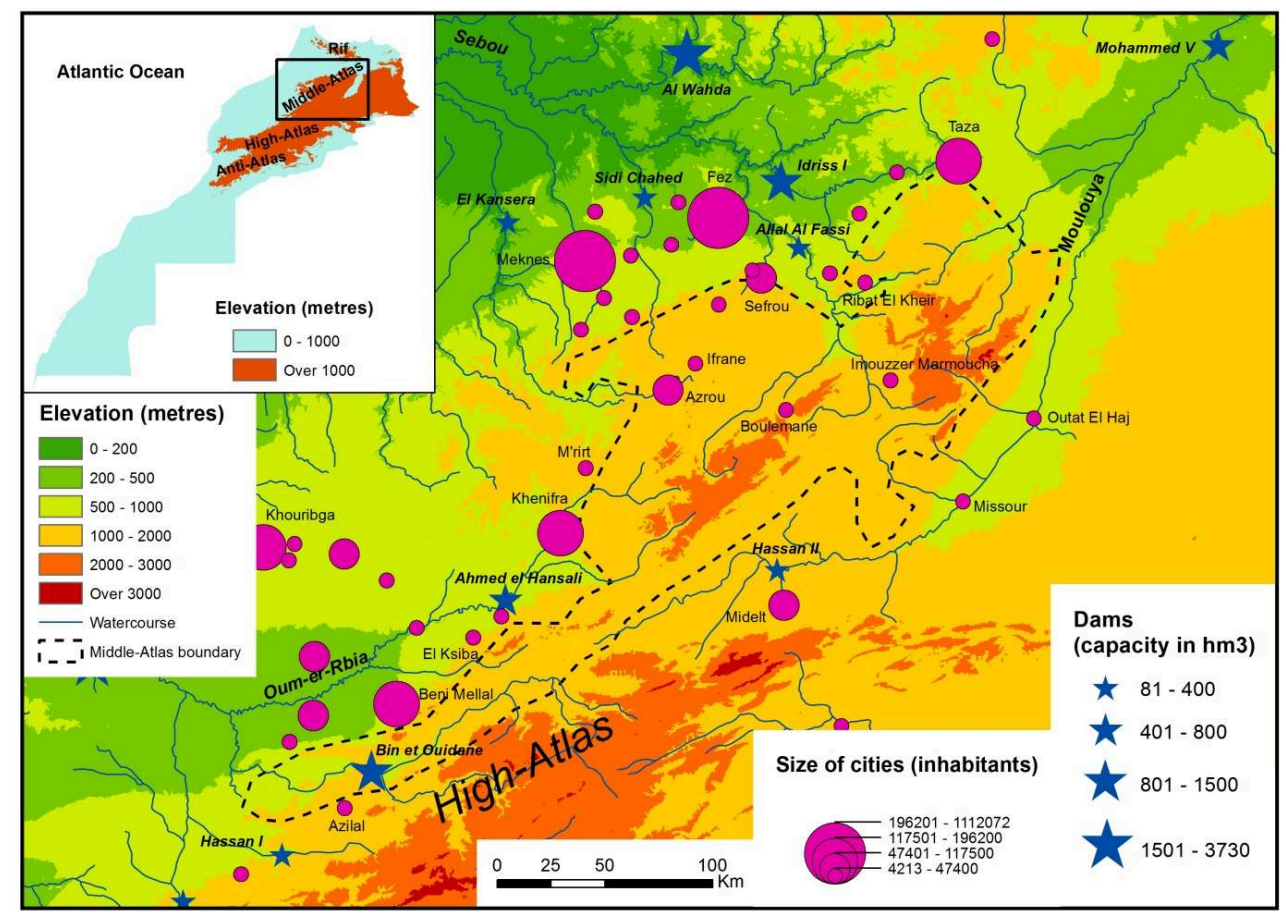

Source: according to RGPH, 2014; FAO, 2015a; amended and supplemented. 


\section{A low mountain with low agricultural potential, conducive to the degradation of forest resources}

Farmland represents only $20 \%$ of the Middle Atlas. This low rate is due to the fact that the local economy was once linked to pastoralism. Nowadays, the economy is based on a rather primitive agriculture associated with ranching and forestry; forests are stateowned and cover $24 \%$ of the total area, compared with $56 \%$ for non-forest rangelands (URBAPLAN, 2006). Topographic, soil and climate constraints weigh on farm life, all the more so because the general population does not have access to sophisticated technical tools. Rural density, around 20 inhabitants $/ \mathrm{km}^{2}$ on average, may reach 150 inhabitants/ $\mathrm{km}^{2}$ in the valleys where land development opportunities are much more widely available.

6 The Middle Atlas is under-urbanised and underequipped in terms of road structures. Small Middle Atlas cities generally resemble big villages. The main towns (Taza, Khenifra, Beni Mellal, etc.) all lie on the edges of the mountains (fig. 1). Urbanisation is largely dependent on rural migration. Half of the rural homeowner households only own enough land for food crops, i.e. less than 5 ha. In addition, there is considerable fluctuation in agricultural production because of the variability of precipitation. As a result, many households, for lack of complementary off-farm activity, have to fall back on livestock by using the forest as a rangeland.

7 Overgrazing is conspicuous in the semi-arid forest floor that covers all the Middle Atlas foothills. Towards the Northwest, in Meknes, positive winter balance $(153 \mathrm{~mm})$ is too sparse to cover the water requirements of plants during the dry season. Southeast of the Middle Atlas, the summer drought is long and severe. Midelt, despite the altitude, displays a total annual precipitation of about $200 \mathrm{~mm}$, and the annual water deficit amounts to $1,072 \mathrm{~mm}$ (fig. 2 and 3). The vegetation is generally composed of espartograss steppe (fig. 4).

Figure 2: Spatial distribution of average annual rainfall (1961-1990) in northern Morocco

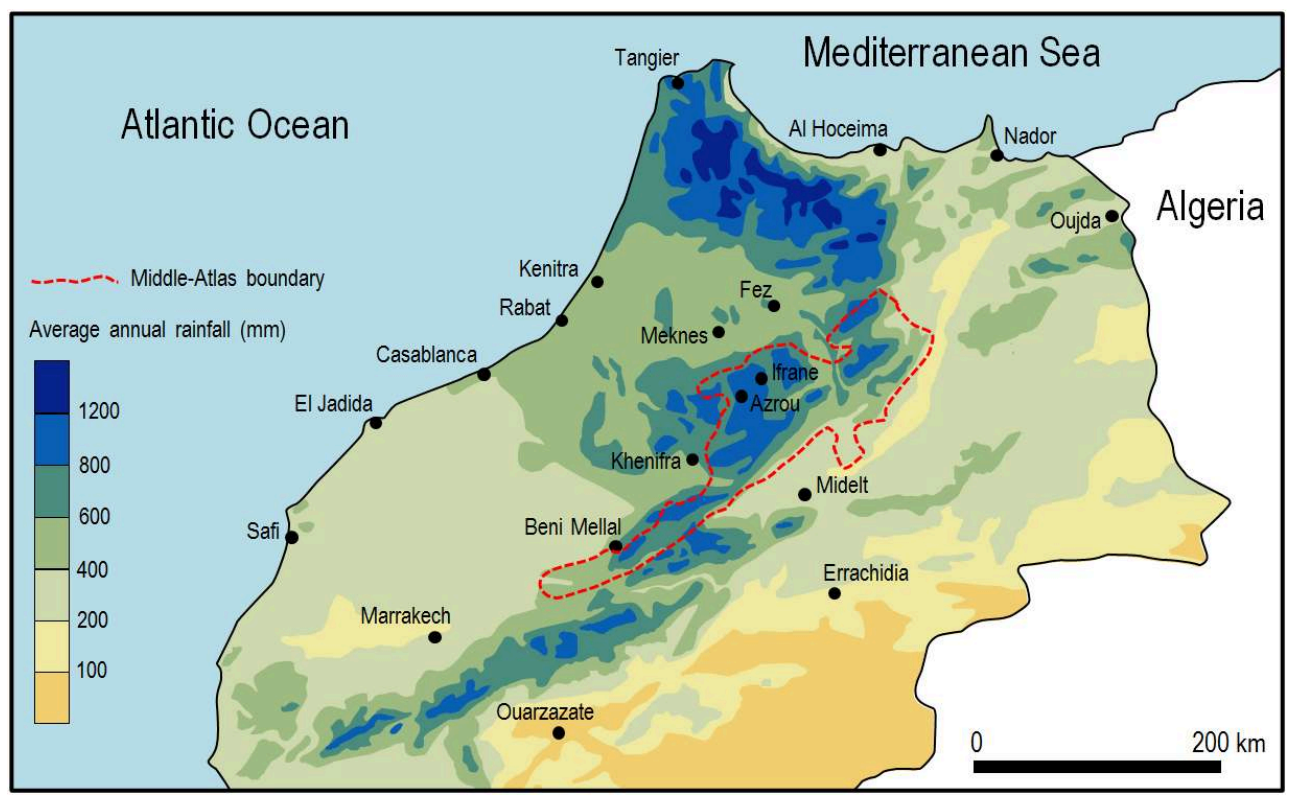

Source: according to Royaume du Maroc, 2000. 
Figure 3: Average (1961-1990 period) climate regime balances (precipitation minus potential evapotranspiration) at three stations located in the Middle Atlas and on its borders

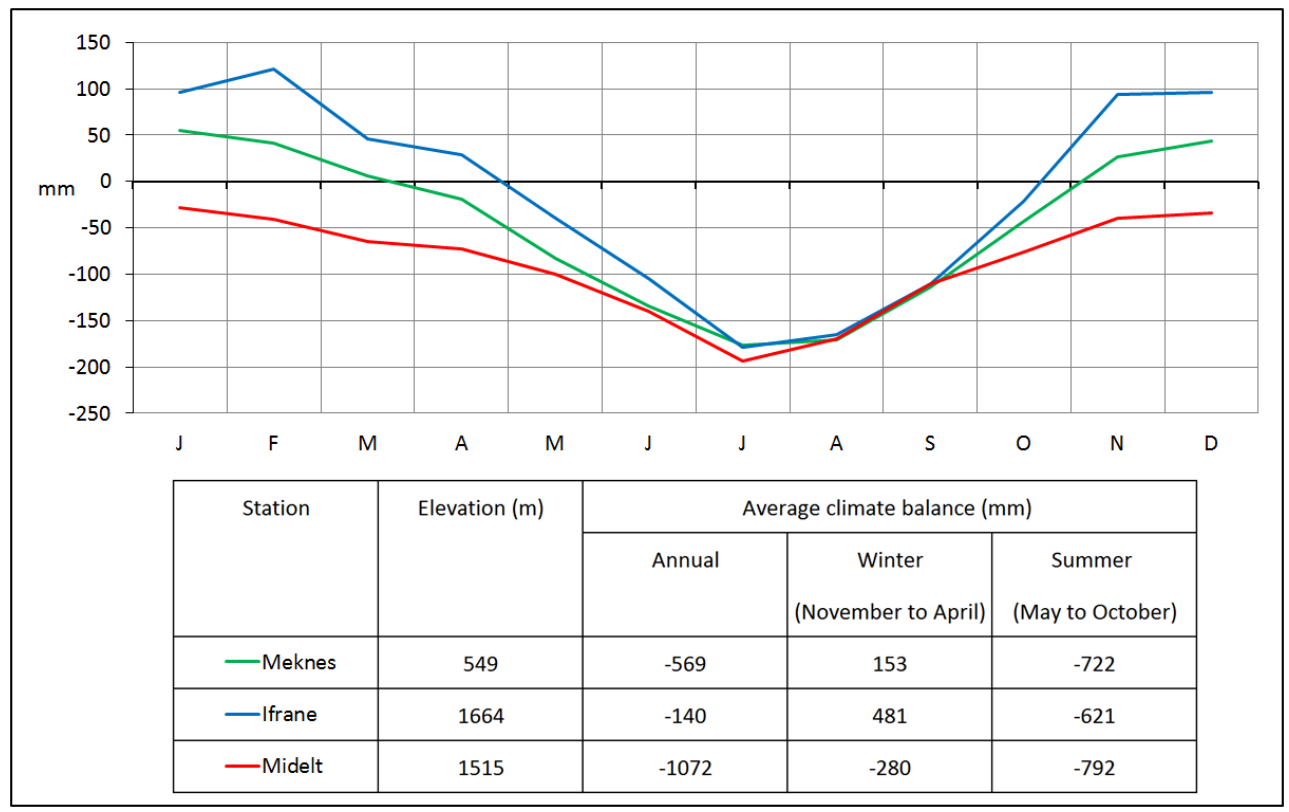

Source: according to FAO, 2015b; WMO, 2015.

Sectors over 1,100 metres are subhumid floor areas. In Ifrane, plants' water requirement balance, which is largely positive in the winter $(481 \mathrm{~mm})$, makes the Middle Atlas the main "water tower" of Morocco. This is green oak territory, up to 2,000 metres, where cedar, already present above 1,500 metres, takes over (fig. 4). The drier climate, particularly in the Southeast, causes a rise in the lower boundary of cedar (Médail \& Quézel, 2003; Rhanem, 2011). Forest species adapt to the summer deficit (-621 $\mathrm{mm}$ ) through low transpiration of smaller, glazed green oak or spiny cedar leaves. Ongoing climate change is negatively affecting this already difficult adaptation.

\section{What evidence of climate change for what future?}

9 The Middle Atlas climate has always been marked by change, as evidenced by the variability of the Holocene climate (Cheddadi et al., 1998) or even, more recently, by the climate of the latter half of the $20^{\text {th }}$ century, where annual average data indicate a temperature rise of about $1.5^{\circ} \mathrm{C}$ over 50 years and a significant precipitation decrease of about $100 \mathrm{~mm}$ (fig. 5 and 6), more markedly since the end of the 1970s. The consequences of these climate developments are visible in the $20-30 \%$ decline in Middle Atlas riverine inputs (Chaponniere \& Smakhtin, 2006; Belhassan et al., 2010). 
Figure 4: Spatial distribution of forest cover in northern Morocco

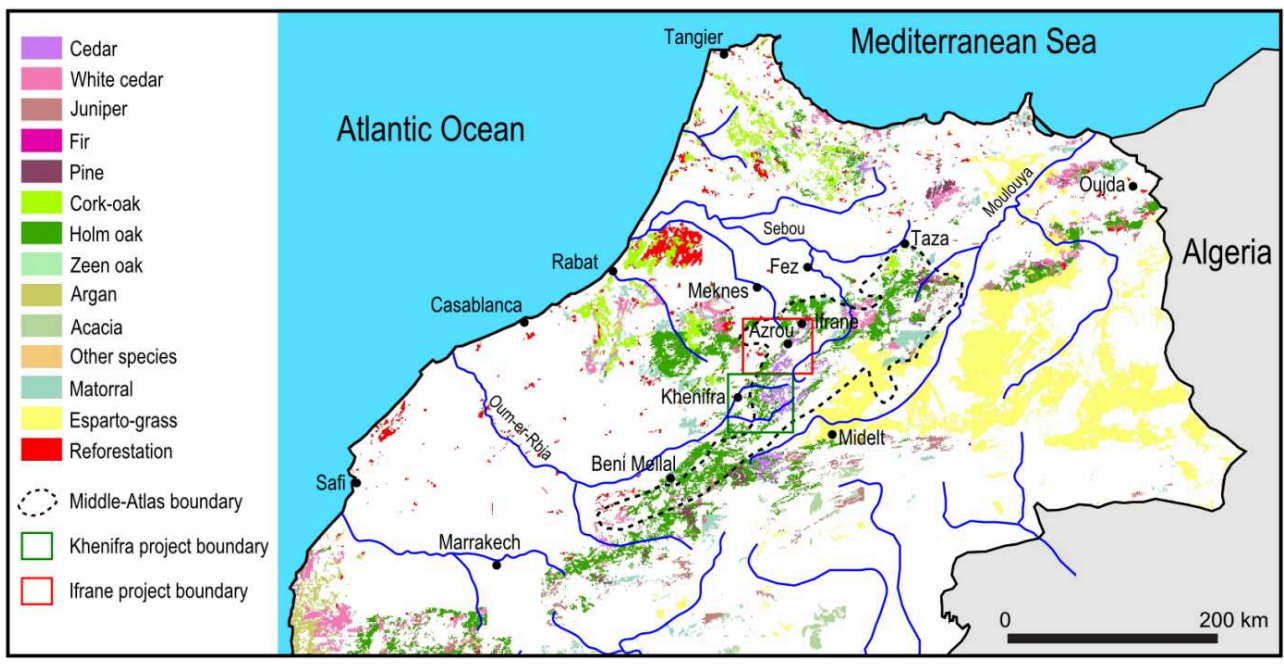

Source: according to the HCEFLCD, 2015.

Figure 5: Evolution of annual precipitation in Ifrane and Meknes from 1934 to 2006

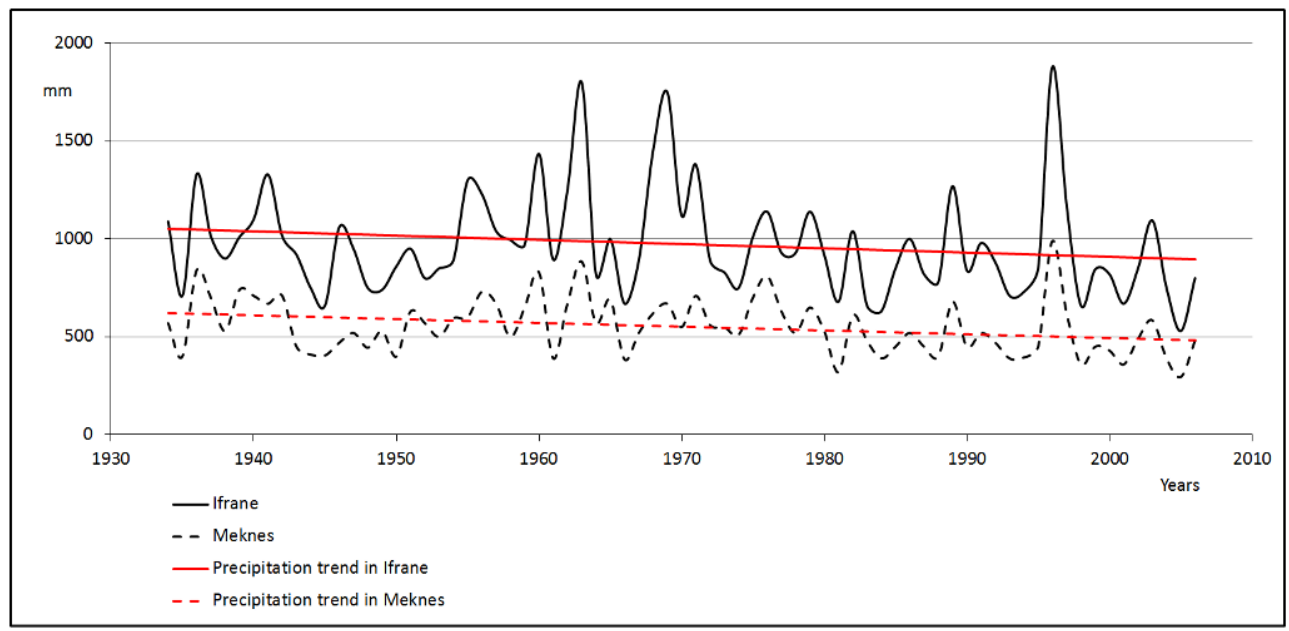

Source: according to Amraoui, 2005; FAO, 2015b. 
Figure 6: Evolution of annual temperatures in Meknes (1961-2010) and Midelt (1973-2010)

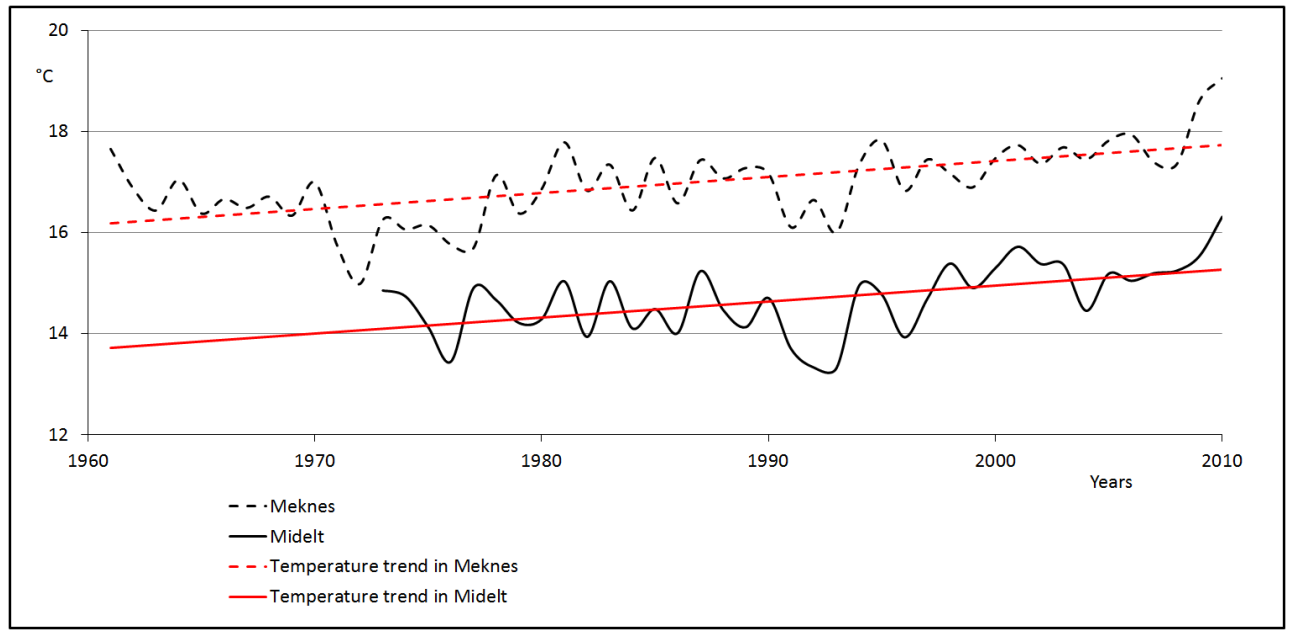

Source: according to FAO, 2015b.

The trends already observed for the Middle Atlas look set to continue during the $21^{\text {st }}$ century (Royaume du Maroc, 2009). On the basis of 1961-1990 records, climate predictions point to a $4-6^{\circ} \mathrm{C}$ warming and a $20-60 \%$ reduction in rainfall towards the end of the century (2071-2099) (fig. 7). These predictions fall short of reflecting the probable reality of future climate change because of not only the poor quality of available climate information but also the low density of weather stations.

On the basis of demographic, economic and hydro-climatic projections, Immerzeel et al. (2011) come to the conclusion that meeting all the water needs of Morocco will be problematic by 2050 whatever the magnitude of climate change in the future. The deficit will be critical on the plains and coastal areas, whose considerable water requirements strongly interfere with the Middle Atlas riverine inputs, which are already affected by climate change (fig. 7). In addition, the impact of riverine inputs on dams is already affected by the silting up of their reservoirs (Taabni \& El Jihad, 2012). These threats provide the state authorities with a useful pretext to launch overhasty anti-erosion programmes under a "rural development" agenda.

Figure 7: Projections of average annual precipitation and temperatures towards 2071-2099 compared with the 1961-1990 period

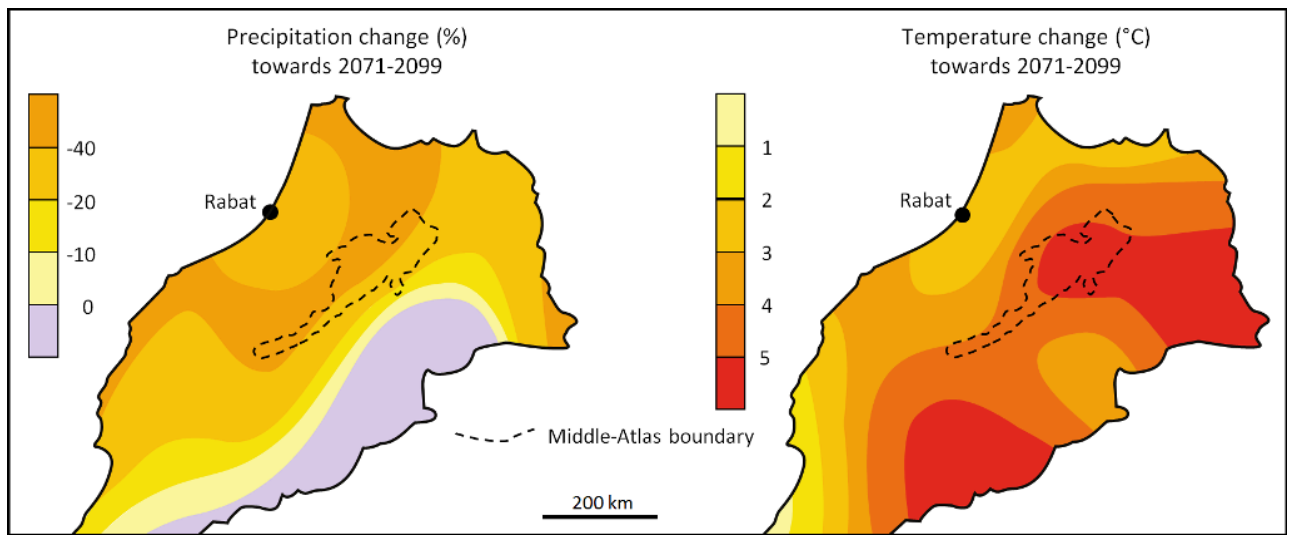

Source: according to Royaume du Maroc, 2009. 


\section{The contradictory logic of rural development at the onset of climate change}

12 In the Middle Atlas, soil erosion is particularly intense in some clay-dominated valleys, like the Valley of Srou (Western Middle Atlas). The importance of river sediment inputs $\left(2,000\right.$ to 3,000 tons $/ \mathrm{km}^{2} /$ year in some places) has meant that the fight against erosion has always been an issue in the basins under study (El Jihad, 1999) and has therefore long been carried out at the expense of rural development itself.

\section{The 1960-1970s: a rural development essentially driven by sector- wide approaches}

13 In the aftermath of World War II, the issues of soil erosion and dam silting were raised by FAO (Food and Agriculture Organization) technicians, who had been commissioned by the colonial authorities. However, unsafe conditions due to the struggle for independence delayed relevant project implementation. The persistence of the colonial doctrine of a "useful Morocco" (plains, coastal areas and large cities) versus a "useless Morocco" (mountains and desert areas) has resulted in "rural development" policies favouring the latter being tailored to meet the needs of the former. The very first project that focused (albeit partly) on the Middle Atlas was the Sebou project, launched in the early 1960s. It was linked to the DERRO (Développement Économique et Rural du Rif Occidental: Economic and Rural Development of the Western Rif) project, whose main objectives were to combat soil erosion and protect the Gharb plain from frequent flooding.

14 The definition of priority intervention areas, considered as potential sources of sediment inputs, largely accounts for the weakness of the results obtained. Indeed, the development of the Gharb plain (construction of about ten dams and irrigation of $300,000 \mathrm{ha}$ ) was the top priority of the project, which was essentially focused on conventional soil erosion treatment, while the socio-economic component was limited to planting a few orchards. Sectoral and technical aspects prevailed over the integrated management of rural development issues, including opening up roads, education and health (Naciri, 1997).

15 After the Sebou project, other RDPs were implemented in the Middle Atlas from the 1970s onwards. Because of the lack of an integrated vision of rural socio-economic issues, these projects focused on combating soil erosion. Despite the meagre income they might draw from working in state-run building projects (reforestation, consolidation of ravines, rehabilitation of badlands, etc.), the participation of beneficiaries has been generally limited, reflecting top-down operation styles (Fay, 1979 and 1986).

\section{The 1980-1990s: climate change as a catalyst for increased population involvement in rural development}

While contributing to the development of modern irrigation in the great plains of Morocco, foreign donors (World Bank, FAO, etc.) repeatedly drew the Moroccan government's attention to the need to strike a balance between the modern irrigation 
sector and the rain-fed agriculture sector, which the overwhelming majority (70 to $80 \%$ ) of small farmers live on. Subsequently, this has become a prerequisite for the granting of funds for the agricultural sector, especially in the mountains, where insurance systems neither support nor adequately assess agricultural vulnerability (Hess et al., 2002).

RDP management units, which were manned by forest engineers, were unable to analyse the socio-economic consequences of agricultural (especially climate-related) vulnerability. A case in point is the Central Middle Atlas Project (CMAP), 32\% of which was funded by the World Bank. This project happened to be implemented during the early 1980s multi-year drought that dealt a huge blow to public finances. The CMAP's activities had to be drastically reduced and were mostly focused on land degraded by erosion (Banque mondiale, 1992; Jennan, 1998).

The weakness of RDPs results often led foreign donors to express reservations about continuing their financial contribution to such projects. It was in this context that the idea for a new generation of RDPs began to emerge. A case in point is the Oued Srou project, undertaken in the early 1990s in the basin of the main tributary of upper Oumer-Rbia. Foreign donors invariably insist, after each incident or blocking, that antierosion measures should be closely linked to a genuine effort for development and income improvement (El Jihad, 2010). Even though RDP management units was gradually strengthened as engineers -mostly agronomists - became involved in the project, the practical implementation of a certain brand of participatory approach of RDPs by these agronomists was thwarted by the lack of genuine commitment from many elected officials and State representatives.

Until the 1990s, RDPs had never stimulated population participation. Indeed, people saw such projects as a way for the State to endorse mountain water mobilisation infrastructure, which only benefits the great plains where commercial irrigated agriculture has developed and captures the lion's share of agricultural investment. Such competition from the plains for mountain water undermines irrigation development opportunities in the Middle Atlas, which currently represents only 2-3\% of the agricultural land (El Jihad, 2001; URBAPLAN, 2006).

\section{The 2000s: participatory approaches that affect forest integration in the agricultural system}

20 Two RDPs, launched in the early 2000s, tentatively implemented participatory strategies under which satisfying people's claims was viewed as the corollary of forest protection. This new generation of RDPs implied cooperation between Morocco through its HCEFLCD (Haut-Commissariat aux Eaux et Forêts et à la Lutte Contre la Désertification: High Commission for Waters and Forests and the Fight against Desertification) - and the European Union (Khenifra project, which covers 2,350 $\mathrm{km}^{2}$ ) and the French Agency for Development (Ifrane project, which covers 3,573 $\mathrm{km}^{2}$ ) (fig. 4).

21 The implementation of these projects was characterised by the major role of antierosion measures, even if it was obscured by the increase of fruit farming on private land to encourage population participation in forest heritage management schemes. Forests are vulnerable not only to firewood collection and land-clearing practices by local people but above all (especially since the 1990s) to criminal activities by mafia 
groups from outside the Middle Atlas, notably illegal charcoal operations and manufacturing cedar wood beams and rafters. It was in this context that four mountain management and development associations (associations de gestion et d'aménagement $d u$ massif, AGAM, Khenifra project) and five silvopastoral associations (associations sylvopastorales, ASP, Ifrane project) emerged from 2007 onwards to encourage comanagement between pastoralists and forest managers. Each of these associations made a multi-year commitment to ensuring the protection of the forest areas it is in charge of in return for an annual grant for the purchase of feed for livestock.

This community-based approach to forest conservation has come up against a number of deficiencies in the region's implementation of socio-economic and cultural transformations. By boosting the need for material products, urban development and the growing success of information and communication technologies (television, mobile phones, Internet...) have turned the exploitation of natural resources into an increasingly individualistic endeavour. This quantitative increase in demand is incompatible with a certain idea of the conservation of a fragile nature, which in the eyes of the local population can only result in low qualitative (i.e. third-rate) development. The effects induced by population growth and poverty amplify the negative impact of climate change on natural resources, making the HCEFLCD reluctant to promote community management of forests.

The Protected Areas Act provides that all actions that might be detrimental to the natural environment are prohibited without the consent of the relevant authority (Royaume du Maroc, 2010). In this context, the rangers, long accustomed to more or less corrupt compromises, are now assigned performance obligations by their hierarchy. This embarrassing situation sometimes leads to tragedy. A local father, caught in the act of cutting cedar wood, was shot dead by a ranger in July 2013 in the protected Ajdir forest, $24 \mathrm{~km}$ east of Khenifra.

In such a tense atmosphere, the very sustainability of the AGAM and ASP and their evolution towards other extended forms (inter-municipal structures, syndicates, etc.) are in jeopardy: firstly, on account of the strict practice of forest "resting", which deprives the populations of forest ranges that they still consider their tribal heritage, and secondly, on account of the jumble of land structures, which weighs heavily on the way forest co-management contracts are designed and implemented on site. Furthermore, the relations between forest managers and farmers are all the more tense since the forest technicians who are in charge of implementing the participatory approach are also in charge of policing forest offences.

Through the AGAM and ASP, public authorities seek to disrupt the age-old tribal boundary of the mountain areas by creating a multitude of national parks. Morocco currently boasts ten parks $\left(8,817 \mathrm{~km}^{2}\right)$ altogether, three of which are located in the Middle Atlas, totalling an area of $3,414 \mathrm{~km}^{2}$ (fig. 8). Those in Ifrane (established in 2004) and Khenifra (established in 2008), extending $1,250 \mathrm{~km}^{2}$ and 2,027 km $\mathrm{km}^{2}$, respectively, are to form the fourth biosphere reserve of Morocco, known as the Cedar Forest Wildlife (HCEFLCD, 2007; Royaume du Maroc, 2011). 
Figure 8: The distribution of parks and of Biological and Ecological Interest Sites (BEIS) in northern Morocco in 2012

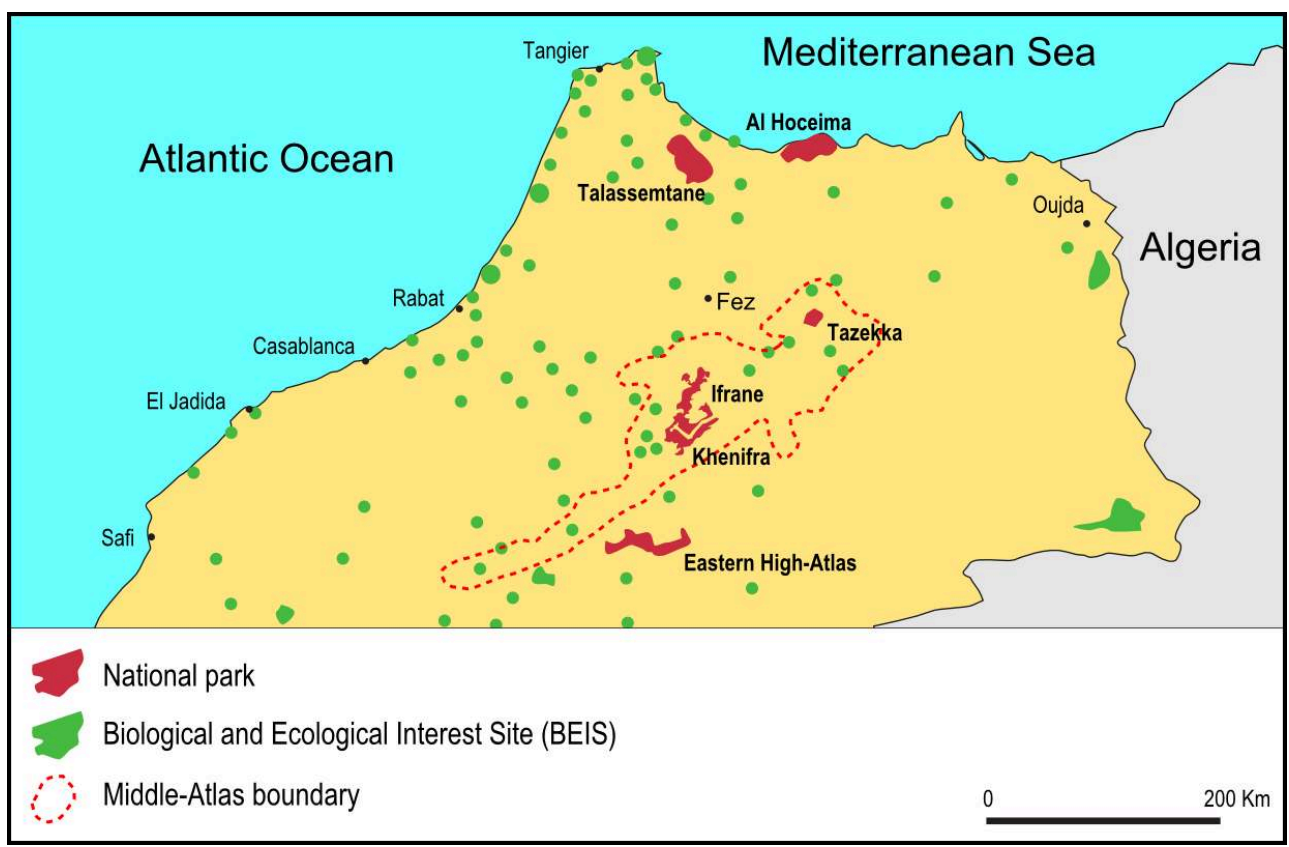

Source: according to Royaume du Maroc, 2014, modified and supplemented.

Despite the willingness displayed by the State to make public participation the cornerstone of effective governance of natural resources, the institutional framework recently renovated in this spirit must, in coming years, come to terms not only with the authoritarian culture of some elected officials and representatives of the State but also with the burdens of a socio-economic context long accustomed to corruption-tainted compromises. This situation is exacerbated by both poverty and illiteracy, which still affected half of Morocco's rural population in 2013 (HCP, 2014). Illiteracy is a major scourge that prevents any real involvement of the people in decision-making processes.

\section{Adaptive strategies: towards territorial resilience and the strengthening of the gender approach}

In Morocco, because of their role as "water producers", the mountains are at the heart of the issue of climate change. This issue comes on top of the importance of mountain forests to the survival of rural populations. The extent of deforestation makes the question of the appropriation of cleared lands the main obstacle to rural development. Moreover, the question of the role of women in rural development emerged in the 1990s and became a major component in the projects that followed.

\section{From rural development to territorial development}

Local residents regard land clearing as a way to remove the presumption that the forest is state-owned and to increase their land areas (Laouina, 2000). The State, arguing that these plots have been torn away from the forest, continues to assert its right to demand their return to the forest. However, the observed dynamics constantly wavers between status quo and slow, reluctant recognition of the ownership rights over these lands. 
Furthermore, the situation of collective rangelands outside forests is no better. Because of the damage they suffer due to public and private activities, these rangelands provide cases where the land status is ambiguous (private, state-owned, collective, etc.).

Forest and non-forest ranges are under pressure from excessive and uncontrollable common grazing rights. These rights (agricultural, pastoral and forest), perpetually granted to local populations, are defined in the 2010 Protected Areas Act as "noncommercial levies intended to cover domestic needs" (Royaume du Maroc, 2010). There is, however, considerable confusion as to what exactly is "commercial" and what "domestic needs" are, since livestock products have always been used by the local population in part as a currency to purchase other goods (food or equipment) or to be saved up for times of economic hardship. Furthermore, the increase in cattle numbers is due not only to locals but mostly to the development of pastoral organisations by both poor rural people who, as forest neighbours, hold the right to use it, and city dwellers who, even though they are economically powerful, are legally excluded from the forest (Mekouar, 1984; Laouina, 2000).

The 2020 rural development strategy (Ministère de l'agriculture, 1999), which advocates multisectoral interventions in mountain areas, lacks a global vision and plans for implementation. Furthermore, it has not fully integrated climate change in the design of the RDPs. In addition, its adoption by other ministries (health, education, etc.) is made quite difficult by the lack of coordination between sectoral policies and territorial approaches. In the face of ceaseless criticism by foreign donors regarding rural development strategy, changes have been made by the government. Therefore, a new funding programme for development, the INDH (Initiative Nationale pour le Développement Humain: National Initiative for Human Development), was launched in 2005. Even though the implementation of the INDH was coordinated by the Ministry of the Interior, the formulation of projects, decentralised at the district level, is the responsibility of Local Human Development Committees. The district level helps avoid any possible confusion with upper, controversial levels (catchment basin, forest massif, etc.) where rural development issues have always been reduced to erosion control.

Even though the INDH was originally designed to fight poverty and insecurity, it must be recognised that most projects aim to improve basic infrastructure in urban and suburban areas. This "urban emergency" is explained by a political will to counter the threats posed by the rise of radical Islam. However, the INDH has breathed new life into territorial development dynamics, both in urban and rural areas, by initiating new relationships between local authorities, the people and state technical services (Planel, 2009). In addition, in 2008 the government took the decision for the first time to separate rural development from agricultural development by entrusting the issue of "rural development" to the Directorate of Planning (Ministry of Urbanism and Planning) under the aegis of the Secretariat of State for Territorial Development (Secrétariat d'État chargé du Développement Territorial, SEDT).

The SEDT (established in 2008) has taken over from the Secretariat of State for Rural Development (Secrétariat d'État chargé du Développement Rural, SEDR, created in 2004 within the Ministry of Agriculture). It is worth noting the semantic change reflecting the emergence of a new attitude. "Rural" (as opposed to "urban", which is a key term denoting modernity) was replaced by "territorial". Perhaps this may indicate the onset of a transition process towards a new development culture in which some traditional nature/society approaches may incorporate new tools and territorial observation 
methods to produce measurable objectives for development? Economic development could increase the negative impact of current climate change, but there is a lack of measurable indicators to assess the potential extent of such an impact on development.

Better rural development adaptation to climate change should lead to intelligent territorial resilience. This would require obtaining territory-related data by highlighting the differing visions of actors involved in territorial development in a framework where consultation and the fluid exchange of information are the watchwords. Even though the plains and coastal areas, as well as their cities, are in the process of building up homogeneous and specialised economic clusters, the mountains and desert regions have yet to find a competitive territorial identity able to promote economic intelligence (Boujrouf, 2014).

The ongoing territorialisation of development policies heralds the end of RDPs such as those driven and implemented first by the Ministry of Agriculture and then by the HCEFLCD (from 2003 to 2008). The role of these institutions in rural development is now limited to reforestation-related activities (HCEFLCD) and purely hydro-agricultural projects (Ministry of Agriculture), especially under the Green Morocco Plan (GMP, started in 2008). By addressing the deficiencies of the INDH in rural areas (especially regarding the improvement of revenues), the GMP fosters the emergence of a new management policy for natural resources and development of local know-how. The Middle Atlas region may evolve into an agricultural cluster dedicated to quality products, whether arboreal (olive-based products, fruit production, etc.) or from livestock (milk, cheese, meat, etc.). The GMP encourages the adoption of "no-regrets" adaptation measures in the event of climate change. Through its second pillar, which aims to improve small-scale agriculture in marginal areas, the GMP largely subsidises arboriculture on sloping land, provided that the beneficiary adopts economic irrigation techniques (especially drip irrigation).

\section{Towards a stronger recognition of the role of women in rural development}

PDRs are partially funded by the Fund for Rural Development (FRD, created in 1994), which at present is jointly managed by the Ministry of Agriculture and the SEDT. The FRD is struggling to fulfil its role because it is not regularly replenished. This justifies the conditional financial support of foreign donors. The eligibility of SEDT projects for foreign funding is now linked not only to the commitments made in the areas of socioeconomic infrastructure relating to basic human rights (roads, schools, health centre, drinking water, etc.) but also to the conditions of rural women's economic integration (Union européenne, 2007).

Beyond the differences in the types of tasks entrusted to men (patriarchal guardianship, representation of the family in the outside world, work in the fields, etc.) and those entrusted to women (educating children, supporting the elderly and disabled, water- and wood-related chores, work in the family fields, etc.), gender inequalities in rural areas mainly involve disparities in access to land (Lamrani, 2013). The issue of women's integration in rural development has always been lacking in the RDPs. The earliest mention of it in Morocco was in the context of the Oued Srou project, where the first experience of micro-credit activity for Moroccan women was launched 
in the early 1990s (El Jihad, 2010). That experience did not lead to convincing results given the patriarchal nature of the rural Middle Atlas society.

The importance of the economic empowerment of rural women and their participation in the decision-making process was widely discussed in the Khenifra and Ifrane projects. Developing water points and equipping households with cooking appliances relieve women of water and fuel chores. Furthermore, this leaves them more time for income-generating activities (IGAs) set up for their benefit (market gardening, small livestock, handicrafts, small trade, etc.). However, foreign donors (who finance 80-90\% of IGAs over the duration of the projects) consider that there is a need for efforts by combating rural female adult illiteracy, which still stood at $63 \%$ nationwide according to 2013 data (HCP, 2014). This scourge affects the success rate of IGAs and their sustainability after project completion. Progress in the fight against illiteracy may be slow, but the development of micro-credit activities has helped many women learn the basics of accounting and, consequently, to make IGAs a sustainable and dynamic process. Even though the sustainability of IGAs lies above all in their limited requirements in terms of fertilisers (animal manure for market gardening) and water (localised irrigation), their opportunities promote short channels. The development of micro-credits and IGAs for rural women is one of the INDH's flagship projects, whose main objective is to reduce gender inequalities and lay the foundations for social justice (Lamrani, 2013). This may also reinforce the resilience of traditional sources of family income (rain-fed cereal crops, extensive breeding, etc.) that are vulnerable to climate change and variability.

\section{Conclusion}

Rural development in the Middle Atlas has often been limited by political choices (usually in favour of the plains) regarding the use of mountain water, whose input is affected not only by the impact of climate change but also by dam silting. These threats have long provided central authorities with reasons to launch anti-erosion programmes financed by international development support funds.

Noting that benefits stemming from RDPs were sectoral, foreign donors have insisted on the need for other approaches more oriented towards direct contact with the population and taking their claims into account. It was to meet this obligation that the Khenifra and Ifrane projects were implemented in the 2000s. Overall, the aforementioned projects were more successful in providing agricultural services than actual socio-economic infrastructure, whose weakness is obviously worrying for several rural districts that are at best demographically stable and at worst depopulated to the benefit of cities. Moreover, attempts to set up community and participatory forest management have not led to concrete results because the population has resisted the state's refusal to integrate forests into the agricultural system (under the pretext of adverse effects of climate change on forest regeneration and land structure disorganisation in sub-forest areas).

It was to find a way out of this conundrum that a new programme for the development of territories (INDH) was put into place in order to address the lack of socio-economic infrastructure and promote income-generating activities. However, this development programme, which focuses on urban areas at the expense of rural areas, would appear to suffer from a lack of an integrated and holistic vision. By addressing the 
shortcomings and delays in implementing INDH projects in rural areas, the GMP has fostered the emergence of a new natural resources management policy in terms of opportunities for the development of the agricultural sector, the main source of jobs in the region. In order to respond to the adverse effects of climate change, this development mainly focuses on promoting extensive farming, arboriculture and economic irrigation techniques. It remains that this development, however, is still highly dependent on integrated management of ecological resources (water, forest, soil, etc.) on the level of the major drainage basins so as to break away from the mountain-plain dichotomy.

Whether or not the population will welcome a territorial policy of economic development or adaptation to climate change will largely depend on the role that the State may assume in local development. With the ongoing regionalisation process, which should strengthen the competences of the regional authorities for development, smart territory governance requires that the State divest itself of its global organising. The State should merely provide civil society with effective institutions and competent officials and ensure compliance with the laws governing society, the economy and the preservation of the environment.

\section{BIBLIOGRAPHY}

Amraoui F., 2005.- Contribution à la connaissance des aquifêres karstiques : cas du lias de la plaine du sais et du causse moyen-atlasique tabulaire (Maroc), Doctoral thesis, Université Hassan II Ain-Chock

(Casablanca), $249 \mathrm{p}$.

Banque mondiale, 1992.- Projet de développement agricole du Moyen-Atlas central (rapport d'achèvement de projet), Banque mondiale, $39 \mathrm{p}$.

Belhassan K., Hessane M-A., Essahlaoui A., 2010.- "Interactions eaux de surface-eaux souterraines : bassin versant de l'Oued Mikkes (Maroc)”, In Hydrological Sciences Journal, 55 (8), pp. 1371-1384.

Boujrouf S., 2014.- "Ressources patrimoniales et développement des territoires touristiques dans le Haut-Atlas et les régions sud du Maroc", Revue de géographie alpine, Dossier no 102-1, http:// rga.revues.org/2259.

Chaponniere A., Smakhtin V., 2006.- "A review of climate change scenarios and preliminary rainfall trend analysis in the Oum-er-Rbia Basin, Morocco", in Working Paper 110 (Drought Series: Paper 8), International Water Management Institute (IWMI), Colombo, Sri Lanka, 16 p.

Cheddadi, R., Lamb, H-F., Guiot, J., Van der Kaars, S., 1998.- "Holocene climatic change in Morocco: a quantitative reconstruction from pollen data", in Climate Dynamics, no 14, pp. 883-890.

El Jihad M-D., 1999.- L'eau dans le haut bassin versant de l'Oum-er-Rbia (Maroc) : ressources, utilisations et conflits, Doctoral thesis, Université de Poitiers, $606 \mathrm{p}$.

El Jihad M-D., 2001.- "L'eau de la montagne et le pouvoir étatique au Maroc, entre le passé et le présent”, in Annales de Géographie, no 622, pp. 665-672. 
El Jihad M-D., 2010.- "Les difficultés de gestion des ressources 'naturelles' et de développement rural dans un milieu anthropisé : l'expérience du Projet Oued Srou (Maroc central)", in Norois, $\mathrm{n}^{\circ}$ 216, pp. 25-45.

FAO, 2015a.- Food and Agriculture Organization, (Bases de données géo-référencées sur les barrages), http://www.fao.org/nr/water/aquastat/dams/indexfra.stm.

FAO, 2015b.- Food and Agriculture Organization, (Bases de données climatologiques), http:// www.fao.org/nr/climpag/index_en.asp.

Fay G., 1979.- Groupements humains, utilisation de l'espace et structures de production dans la zone 3-4 (Moyen Atlas, Plateau central), Rabat, MARA-PNUD, $100 \mathrm{p}$.

Fay G., 1986.- "Désagrégation des collectivités et dégradation des milieux dans le Haut-Atlas marocain”, in Revue de l'Occident musulman et de la Méditerranée, no 41/42, pp. 234-248.

HCEFLCD, 2007.- Plan d'aménagement et de gestion du parc national d'Ifrane, stratégie de conservation et principes de zonage, Haut-Commissariat aux Eaux et Forêts et à la Lutte Contre la Désertification, Rabat, 65 p.

HCEFLCD, 2015.- Haut-Commissariat aux Eaux et Forêts et à la Lutte Contre la Désertification, http://www.eauxetforets.gov.ma/fr/index.aspx.

HCP, 2014.- La femme marocaine en chiffres : Tendances d'évolution des caractéristiques démographiques et socioprofessionnelles, Haut-commissariat au plan, Rabat, $121 \mathrm{p}$.

Hess U., Richter D., Stoppa A., 2002.- "Weather risk management for agriculture and agribusiness in developing countries", in Climate Risk and the Weather Market, London, Risk Books, 16 p.

Immerzeel W., Droogers P., Terink W., Hoogeveen J., Hellegers P., Bierkens M., Van Beek R., 2011.- Middle-East and Northern Africa water outlook, Report Future Water (98), Wageningen (Netherlands), $136 \mathrm{p}$.

Jennan L., 1998.- Le Moyen-Atlas et ses bordures : mutations récentes et dynamique de l'espace et de la société rurale, Doctoral thesis, Université François Rabelais, Tours, 706 p.

Lamrani N., 2013.- Améliorer l'accès au financement pour renforcer l'autonomisation des femmes rurales en Afrique du Nord : bonnes pratiques et leçons à tirer (cas du Maroc), Commission économique des Nations Unies pour l'Afrique, $37 \mathrm{p}$.

Laouina A., 2000.- Le développement des espaces péri-forestiers, in Les espaces périphériques au Maroc et au Maghreb à l'heure de la mondialisation, Université Mohamed V, Rabat, pp. 161-182.

Médail F., Quézel P., 2003.- "Conséquences écologiques possibles des changements climatiques sur la flore et la végétation du bassin méditerranéen", in Bocconea 16 (1), pp. 397-422.

Mekouar M-A., 1984.- "Forêt et environnement en droit marocain", in Forêts et environnements, PUF, Limoges, pp. 183-198.

Ministère de l'Agriculture, 1999.- Stratégie 2020 de développement rural, Rabat, 293 p.

Naciri M., 1997.- "Les montagnes marocaines, de la centralité à la marginalisation : réflexions pour une réinsertion des massifs montagneux dans l'espace national”, in les zones défavorisées méditerranéennes, L'Harmattan, Paris, pp. 51-69.

Planel S., 2009.- “Transformations de l'État et politiques territoriales dans le Maroc contemporain", in L'Espace Politique, no 1, http://espacepolitique.revues.org/1234. 
RGPH, 2014.- Recensement général de la population et de l'habitat (2014), http://www.hcp.ma/Notesur-les-premiers-resultats-du-Recensement-General-de-la-Population-et-de-l-

Habitat-2014_a1516.html.

Rhanem M., 2011.- “Aridification du climat régional et remontée de la limite inférieure du cèdre de l'Atlas (Cedrus atlantica Manetti) aux confins de la plaine de Midelt (Maroc)", in Physio-Géo, Volume 5, pp. 143-165.

Rosière S., 2007.- Géographie politique et géopolitique, une grammaire de l'espace politique, Ellipses, Paris, $426 \mathrm{p}$.

Royaume du Maroc, 2000.- Le territoire marocain : état des lieux, Ministère de l'aménagement du territoire, de l'environnement, de l'urbanisme et de l'habitat, Éditions Okad, Rabat, 128 p.

Royaume du Maroc, 2009.- Plan national de lutte contre le réchauffement climatique, Ministère de l'Énergie, des Mines, de l'Eau et de l'Environnement, (Département de l'Environnement), Rabat, $35 \mathrm{p}$.

Royaume du Maroc, 2010.- Loi n 22-07 relative aux aires protégées promulguée par le dahir n 1-10-123 du 3 chaabane 1431 (16 juillet 2010), Al Hoceima, 17 p.

Royaume du Maroc, 2011.- Indicateurs du développement durable du Maroc (rapport national), Ministère de l'Énergie, des Mines, de l'Eau et de l'Environnement (Département de l'Environnement), Rabat, 164 p.

Royaume du Maroc, 2014.- Cinquième rapport national sur la mise en cuvre de la convention sur la diversité biologique, Rabat, 135 p.

Taabni M., El Jihad M-D., 2012.- "Eau et changement climatique au Maghreb : quelles stratégies d'adaptation ?", in Les Cahiers d'Outre-Mer, no 260, pp. 493-518.

Union européenne, 2007.- Maroc, document de stratégie (2007-2013), Union européenne, Bruxelles, $41 \mathrm{p}$.

URBAPLAN, 2006.- Étude sur la stratégie d'aménagement et de développement du Moyen-Atlas : Synthèse finale (phase 2, rapport $n^{\circ}$ 5), Lausanne et Rabat, $67 \mathrm{p}$.

WMO, 2014.- World Meteorological Organization, http://www.wmo.int/datastat/ wmodata_fr.html.

\section{ABSTRACTS}

In Morocco, studies on the relationship between climate change and rural development policies, especially in the mountains, are few and far between. This article takes a geopolitical approach to this particular issue in the Middle Atlas. Until the 1990s, rural development policies were based on the fight against forest degradation and soil erosion, first and foremost with a view to reducing dam silting. Since the early 2000s, efforts have focused on direct contact with the population in order to meet their needs. However, integration of the forestry sector into the agricultural system has not yielded the expected results. People, deeply concerned by the multifaceted impacts of climate change, have not been particularly receptive to sectoral proposals of projects related to forest heritage management. To address this concern, new development programs have been implemented and decentralised at the municipal level. Although projects still fall short of needs, the new approach to rural development is more territorial in terms of improving the resilience of populations to climate change at present and in the future. 
INDEX

Keywords: climate change, mountain ecosystems, rural development, Middle Atlas, Morocco

\section{AUTHOR}

MOULAY-DRISS EL JIHAD

Ruralités, MSHS (Bâtiment A5), Université de Poitiers. 5, rue Théodore Lefebvre - TSA 21103, 86073 Poitiers Cedex 9, France

d.eljihad@yahoo.fr 